Article

\title{
"Action Space" Based Urban Land Governance Pattern: Implication in Managing Informal Settlements from the Perspective of Low-Income Housing
}

\author{
Reshma Shrestha ${ }^{1,2, *}$, Jaap Zevenbergen ${ }^{1}$, Fahria Masum ${ }^{3}$ and Mahesh Banskota ${ }^{4}$ \\ 1 Faculty of Geo-Information Science and Earth Observation of the University of Twente, \\ 7500 AE Enschede, The Netherlands; j.a.zevenbergen@utwente.nl \\ 2 School of Engineering, Kathmandu University, Dhulikhel, Post Box 6250, Nepal \\ 3 Land Management Consultant, Connollystrasse 26, 80809 Munich, Germany; masum@landguidance.com \\ 4 School of Arts, Kathmandu University, Hattiban, Lalitpur, Post Box 6250, Nepal; mbanskota@ku.edu.np \\ * Correspondence: r.shrestha-1@utwente.nl
}

Received: 30 May 2018; Accepted: 22 June 2018; Published: 27 June 2018

check for updates

\begin{abstract}
Understanding the governance pattern between civil society and market actors in allocation, access to, and use of land for low-income housing is important in managing the informal settlement. In this study, the concept of "action space" is conceptualized as a means to analyze the interaction between civil society and market actors. This novel approach is then applied to a resettlement project in Nepal as a case study. The analysis revealed the mechanism by which the "action space" was created and the push and pull of the "action space" among actors that led to various types of legitimacy. The results show that due to a regulatory vacuum a gap between market legitimacy and social legitimacy was created, resulting in a failure to cater land for low-income housing. Analysis of governance patterns using the lens of "action space" offers an important perspective on how to minimize the gap between market legitimacy and social legitimacy.
\end{abstract}

Keywords: "action space"; civil society and market actors; informal settlements; land for low-income housing

\section{Introduction}

Managing informal settlement in a sustainable manner is a global south issue that is associated with land and housing for low-income groups. According to Mason and Fraser [1], managing informal settlements entails improving the quality of life of informal settlers by providing tenure security on land and housing, as well as providing access to basic services with an acceptable standard. In order to manage informal settlement, Augustinus [2] has argued for two types of interventions-a proactive intervention and a reactive intervention. With the proactive intervention, low-income housing is provided to the low-income groups. On the other hand, with the reactive intervention in situ upgrading of settlements or relocation of the informal settlers are carried out by providing security on land and housing tenure. When a settlement is located in an environmentally vulnerable zone, the relocation intervention is a better approach to managing the informal settlements [3]. Regardless of intervention type, several authors [4,5] consider the access to, allocation of affordable land as well as the use of land as a prime factor in the housing for low-income groups. Yet, existing challenges are associated with acquiring land for housing low-income groups [6]. This has been attributed to the weakness of urban land governance in catering land for low-income housing. 
The major weakness in the urban land governance is the lack of balanced action among the three key actors: government, market, and civil society in the governance pattern [7]. The governance patterns basically refer to the action of various actors like government, civil society, and market and their dominant position in that period of action such as government-led governance, market-led governance, and civil-society-led governance [8]. For instance, Blessing [9] has shown "state" and "market" dualism as core challenges in housing the low-income groups and concluded that the government and market need to take an integrated action. Similarly, the conceptualization of hybrid governance within the housing research has further amplified the importance to understand the blended action and the logic of government, market and civil society in the framework of social enterprise [10].

The different logic of different actors in the governance pattern refers to various types of legitimacy. In this regard, the challenges that urban land governance faces are to enhance legitimacy in order to obtain optimal outcome to accommodate low-income groups [7,11]. Legitimacy is defined as "a generalized perception or assumption that the actions of an entity are desirable, proper, or appropriate within some socially constructed systems of norms, values, beliefs, and definitions" [12]. Various authors have referred to different types of legitimacy in their studies-pragmatic, moral and cognitive legitimacy [13], legal and social legitimacy [7,13], and market legitimacy [14]. In this paper, we refer to two types of legitimacy: social legitimacy and market legitimacy. In the market-led governance, the market does not accommodate the low-income groups due to lack of market legitimacy for allocating land for low-income housing. While considering market legitimacy for land development, it is a generalized perception that the actions of entity fulfill the market norms and value and the developed land support the economic growth. According to Durand-Lasserve [15], there is a global context where land developed for economic growth is rarely allocated for housing the low-income groups because it requires land below market value. In contrast, the civil society-led governance pattern considers various social norms that need to be incorporated. Shrestha et al. [7] have explained the importance of social legitimacy, which is important to incorporate while considering low-income housing. Therefore, there seems to be a gap between social legitimacy and market legitimacy. The improvement of the urban land governance is embedded in minimizing the gap by considering the interaction between civil society and market actors.

The importance of the role of civil society and market actors are advocated in various studies. Ndezi [16] has mentioned the importance of community-based organizations (CBOs), NGOs getting involved in the resettlement process in a Tanzania case that shows how the weakness in policies and institutional framework can limit the participation. Similarly, Patel et al. [17] have shown that by involving the community from the initial phase of a resettlement project in collaboration with CBOs, NGOs have led to success. Yntiso [18] argued for the participatory approach to involve communities and potential partners in decision making in order to understand their social needs. At the same line, Keuk et al. [19] and Amado et al. [20] have forwarded various shortcomings in the resettlement approaches that range from infrastructure provision to land tenure security due to the lack of an effective participatory framework to incorporate the private actors while constructing low-income housing. In addition, Garau [21] has mentioned that besides technical support, physical interaction between actors is equally important for achieving an effective outcome in the participation process. Yet, the mechanism of interaction between market and civil society and their governance pattern remains widely unexplored with regard to providing affordable land for housing low-income groups.

In order to understand the interaction among actors as well as the overarching governance pattern, various authors have applied the concept of "action space" in their studies [7,8]. Similarly, Kågström and Richardson [22] have conceptualized the space of action to understand the practitioners' "potential spaces for action", "actual spaces for action" and "interpretative spaces for action" while conducting Environmental Impact Assessment (EIA). Following Foxon [8], this paper uses "action space" as a lens to understand the governance pattern and conceptualize it in the access to and allocation of land for low-income groups in order to manage informal settlements. 
In this study, we analyze the governance pattern within the concept of "action space" and its legitimacy. We focus on the interaction between market actors and civil society actors in access, allocation, and use of land for housing low-income groups. Though we highlighted the role of the market and civil society actors, the role of the government cannot be excluded. Therefore, we consider the government role as overarching. The case of resettlement of informal settlers in Kathmandu, Nepal was studied to understand the governance pattern using the "action space" concept. The paper finally provides the way forward to balance the "action space" of civil society actors and market actors.

\section{Urban Land Governance and Legitimacy in Managing Informal Settlement}

While referring to the weakness of urban land governance in allocating affordable land for low-income housing, the underlying challenges are about legitimacy [11]. Shrestha et al. [7] have shown that different governance patterns have different types of legitimacy. The state-led governance has legal legitimacy, while civil-society-led governance has social legitimacy. The authors have further shown that in order to manage informal settlements, the gap between legal legitimacy and social legitimacy in allocating land for housing the informal settlers needs to be minimized. Furthermore, the holistic approach hinted towards considering the market actors. While doing so, there is a challenge of dealing with market legitimacy because in the market-led governance the market does not automatically accommodate the low-income groups [14].

The social legitimacy is about considering the social norms and value and these are the essences of the civil society-led governance. The civil society-led governance pattern provides effective results in identifying land for housing low-income groups by applying a tool like a community-led enumeration. The approach adopted by the informal settlement federation of Mumbai was set as good practices of community-led governance, in which the community led to a land use plan that was considered as the driving factor for enhancing livelihood options. Kigochie [23] has also shown that allocating land for house-based enterprises supported the income generating activities of the residents (The term 'Residents' is used to refer to the informal settlers who are resettled in formal housing) at the relocated site. In addition, Patel et al. [24] have explained the involvement of the community in gathering the information of available land and succeeding in achieving the social legitimacy. The information such as land ownership, available infrastructure, job options, and cost of the commuters to their present place of work helped to incorporate the social requirement of the informal settlers. Moreover, the information about the affordability of the land helped the community-led saving groups and informal settlers' federation in planning the relocation strategy.

Similarly, market legitimacy is considered important in the market-led governance pattern while allocating part of their development to low-income housing. In the resettlement project, various literature $[4,25]$ have shown that access to affordable land from the formal market is one of the critical factors that hinders development of low-income housing. In the similar line, Needham and de Kam [26] have highlighted various constraints that affect the land provision for low-income housing, for instance, unaffordable land prices under formal market conditions, less profit in low-income housing, the effects on a land value near low-income housing. Therefore, market legitimacy is important while enabling the market to contribute to the social goal.

\section{The Concept of "Action Space" to Analyze Governance Pattern}

The "action space" is an analytical concept to analyze the various governance patterns, i.e., government, civil society, or market led governance pattern. It provides the framework for analyzing the interaction between each combination of actors through their inter-relationships [27]. In order to conceptualize the interaction, governance pattern and legitimacy between market and civil society, the concepts of "citizen entrepreneurship" and "compliant consumer" are integrated into the "action space" as shown in Figure 1. If the "action space" is pulled towards the civil society actors, a new breed of "citizen entrepreneur" can be seen. Similarly, if the "action space" is pulled towards the market then "compliant consumer" arise-in which the market is seen to 'know best' and consumers simply comply with the price signals that the market sends. 


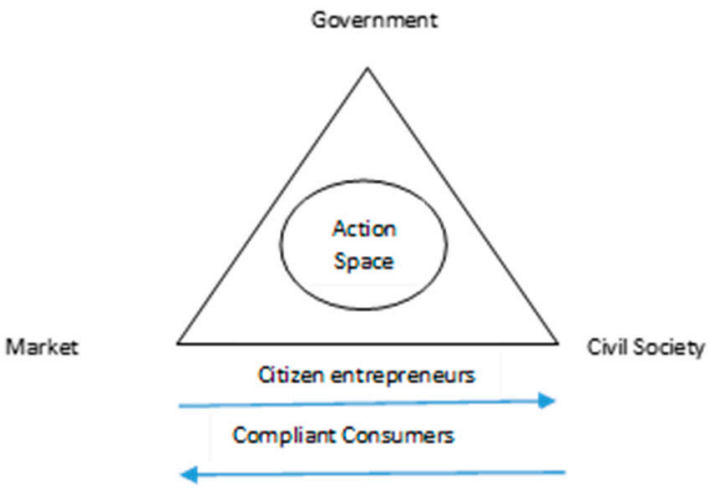

Figure 1. "Action Space" [27].

\subsection{The Citizen Entrepreneurs within the Context of Social Entrepreneurs}

The "citizen entrepreneur" and "social entrepreneur" are inter-related concepts and are used interchangeably. The activities conducted by the citizen with profit goal is considered as "citizen entrepreneur" and when the entrepreneurship is oriented to the societal benefits rather than profit making, it is referred to as "social entrepreneur" [28] . It is materialized through the social indicators like participatory nature, an initiative launched by citizens, the social aim of the actions, which are performed to benefit the society by involving the affected citizens.

The social entrepreneur sets the "action space" created by civil society actor to achieve the social goal through economic orientation. There have been various studies that show the importance of social entrepreneurs in the housing sector for low-income groups [10,29]. Czischke et al. [10] have conceptualized the role of the state, market, and civil society within the framework of a social enterprise in the housing sector depending upon mission and goal. Within the context of the social enterprise, social entrepreneurs are groomed in the civil society sector, where the activities refer to the economics-oriented towards a social goal. In some studies, this is referred to as hybrid governance as there is not a dominant logic of a single actor [30].

The activities of civil society oriented from the economic perspective towards social goals are emerging in housing the low-income groups. Tripathi and Agarwal [31] have mentioned that "action spaces" created by civil society groups towards social entrepreneurship has empowered the informal settlers in managing their own land and housing, as well as in strengthening their economic condition. The evidence was set in the Indian case about the social entrepreneurship in the form of slum welfare cooperatives, housing cooperatives and banking cooperatives that facilitate the land and housing sector for low-income groups.

Social entrepreneurship, which is boosted by land use plan, is highlighted as an important component of resettlement plans for informal settlers. Kigochie [23] has demonstrated that creating the "action space" in the income generating activities by providing land for initiating home-based enterprises has made the resettlement plan for the informal settlers successful. The success case of the Mumbai resettlement project shows that the "action space" of community organization is created in the resettlement process by involving informal settlers in the selection of land, planning, and designing of resettlement plan and managing financial resources through women cooperatives [17].

The above theoretical background supports the analytical framework of the "action space" of civil society within the context of a social entrepreneur (see Figure 2). As shown in Table 1: the role of a social entrepreneur can be contextualized differently at the strategy level and project level. The social entrepreneurs in the strategy level contribute to the access to land for low-income housing. Similarly, at the project level, the land use plan can create "action space" that can support social entrepreneurship by individual residents. 
Table 1. Analytical framework of the Social Entrepreneur.

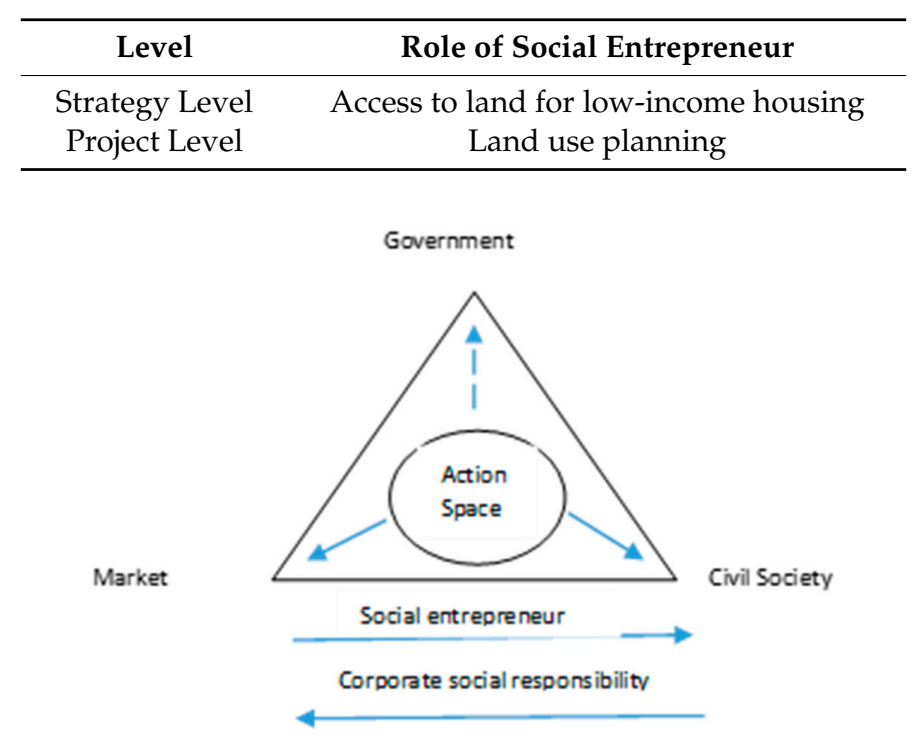

Figure 2. "Action Space" framework (modified by the author).

\subsection{Compliant Consumer within the Context of Corporate Social Responsibility (CSR)}

The "compliant consumer" is conceptualized in the market-led governance by Foxon et al. [27] and refers to the target groups who are compatible with the price signal sent by the market. Within the context of land development, market-led governance refers to the sole action of private developers in the provision of developed land. In the market dominant governance, the consumers are usually high-income groups who can afford the price in the formal market for land and housing. As such, this formal market does not serve the affordable land for housing low-income groups. Therefore, to bring the low-income groups within the "compliant consumer" there is a pressing need for the market intervention. In this context, the Corporate Social Responsibility (CSR) has been found to be conceptualized in the housing research to incorporate low-income groups [32].

CSR has been brought into practice in different contexts in order to pull the market actors towards social goals. CSR has been considered as a concept in bringing the consensus amongst private sectors to extend the role and responsibility of business beyond profit-seeking and in which companies see themselves as a part of a wider social system [33]. Within this context, as highlighted in Turk and Altes [25], via CSR, the government can bring the intervention in the market sector with market legitimacy to obtain the social goal. Tang et al. [34] has provided evidence in the Chinese case about the role of government in guiding private enterprises to fulfill CSR.

Several authors have agreed on CSR as a potential concept to incorporate private developers in the allocation of land for affordable housing [25,35]. Similarly, Othman and Mia [32] have shown the use of CSR to involve SAQS (South African Quantity Surveyors), a private sector, for technical support in facilitating housing development at low cost. The authors have mentioned the various actions, which hinders the delivery of housing for the poor, promoting community involvement in the design process. CSR has also been considered in facilitating the financial process in acquiring land and housing as well as in information counseling to develop low-income housing. Likewise, Adams et al. [35] have mentioned the CSR as an approach to enforce the developers to allocate land for low-income housing. It can be applied as a condition to obtaining the development permits for the private developers. In addition, Gooding [36] has indicated that the intervention in private sector housing provision under a theme like CSR is a feasible way to effectively meet the land and housing need of low-income families. Aligning with the provision of low-income housing, Wilson et al. [37] have shown that the regulatory vacuum to use the CSR of the private sector in allocating land for 
low-income housing has affected the low-income groups in the case of Pennsylvania. Therefore, CSR is the potential concept to direct the private developers' action towards social goal as well.

The above theoretical background supports the analytical framework of the "action space" of market actors within the context of CSR (see Figure 2). As shown in the Table 2, the role of the CSR can be contextualized differently at the strategy level and project level. The CSR at the strategy level contributes to the allocation of land for low-income housing. Similarly, at the project level, the technical support for land and housing development can be regulated with CSR.

Table 2. Analytical framework of corporate social responsibility.

\begin{tabular}{cl}
\hline Level & Role of Corporate Social Responsibility \\
\hline Strategy Level & Allocation of land for low-income housing \\
Project Level & Technical Support for low-income housing \\
\hline
\end{tabular}

\section{Methodology}

The "action space", which is the analytical framework for analyzing governance pattern, is conceptualized here to understand the interaction between civil society actors and market actors in managing informal settlements. This novel approach was applied in the case of a resettlement project named the Kirtipur Housing Project (KHP) in Kathmandu, Nepal.

The case was analyzed using the scale and level concept. According to Cash et al. [38], the mismatch in the scale and level is one of the challenges in governance. Gibson et al. [39] defined "scale" as spatial, quantitative, analytical dimensions applied to study any phenomenon and "level" as the unit of analysis, which is located at different positions on the scale. Cash et al. [38] have presented schematic illustrations of different scales and levels. In this study, we applied the management scale, which consists of different levels. We have combined the policy and strategy level to one level and then to project level to analyze the governance pattern.

Data were collected using a semi-structured household interview with the residents of KHP, a semi-structured interview with key informants and a review of documents related to case sites. Applying the scales and levels as adopted in this study, we gathered the views of residents within the period of two years (December 2013 and March 2016). The latter field visit was conducted after the devastating earthquake of 2015 in Nepal, with the rationale to strengthen the data collected in 2013. Altogether 27 respondents participated in the household interviews in both years. Additionally, participants for semi-structured interviews included key informants of the KHP, government actors, civil society actors, NGOs, and market actors. The semi-structured interview was directed towards collecting an overview of land/housing policy and practices for low-income housing. The review of literature was carried out to understand the process of resettlement at the project level.

\section{Case Study}

\subsection{The Kirtipur Housing Project (KHP)}

The Kirtipur Housing Project (KHP) is a resettlement project for informal settlements residing along the Vishnumati River banks in the Kathmandu Valley (see Figure 3). The three actors (government, market, and civil society) were involved in this project. However, the project was dominantly led by the civil societies (see for detail [40]). Table 3 shows the role of three key actors-government, market, and civil society-in the KHP.

In January 2002, the government published a notice for the clearance of the road construction site. In response to this notice, the affected informal settlers with the support from Lumanti support group (NGO), squatter federations, other NGOs and civic groups resisted for the demolition plan of government of their houses without an alternative resettlement plan. The lobbying from Lumanti succeeded to make the "landmark agreement". The agreement stated that the informal settlers identified as "genuine settlers" would be provided with financial support for rental accommodation for three months and thereafter they would be provided with an alternative housing [40]. 
In April 2002, the settlements were demolished. The informal settlers moved to the rental houses in a nearby area. During the process, Lumanti had frequent contacts with the informal settlers to plan for the relocation. Unfortunately, in June 2002, political upheavals in the government system led to the dissolution of all the elected local bodies and dismissal of the Mayor. This affected the implementation of the "landmark agreement".

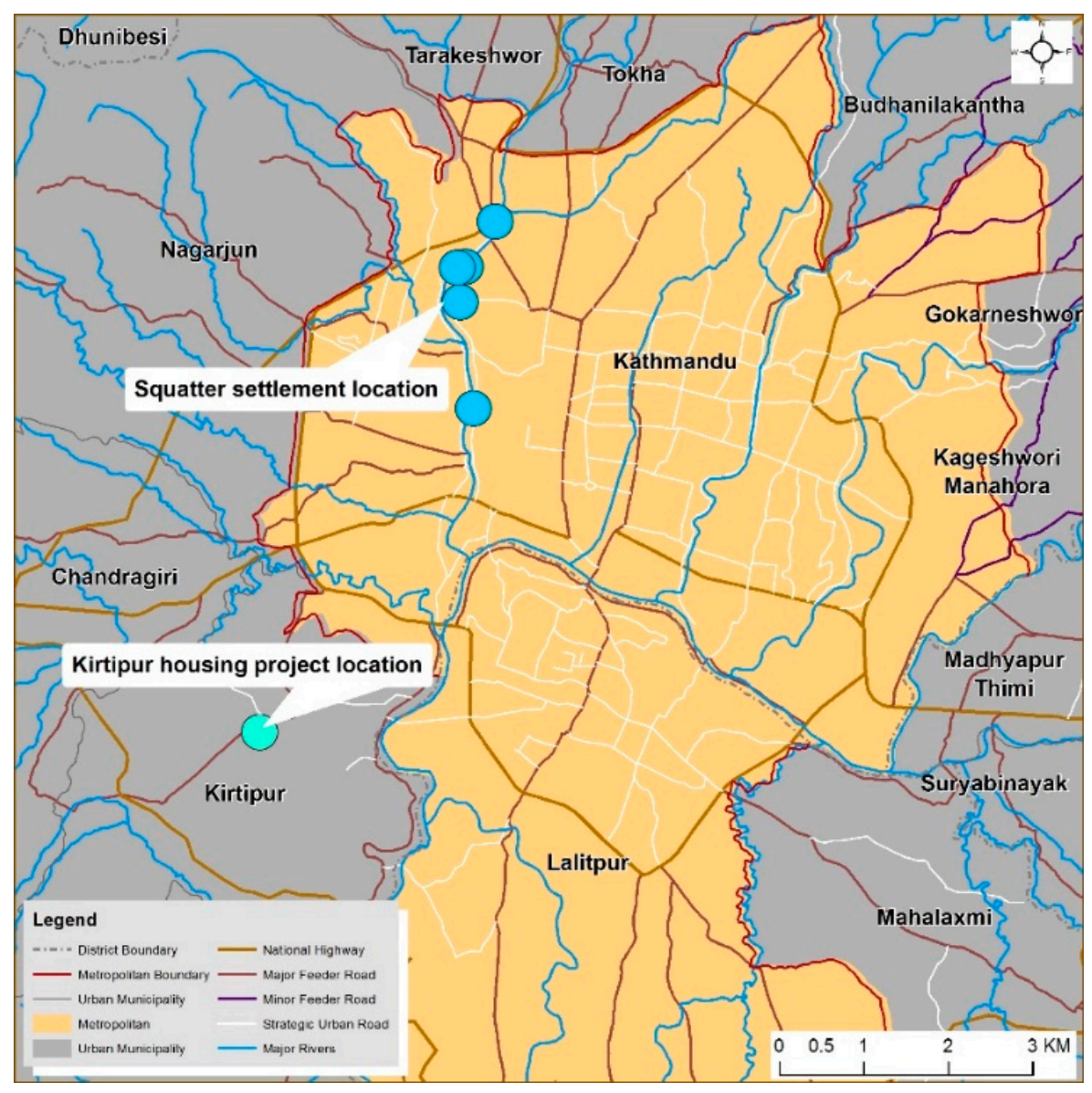

Figure 3. Location Map of relocated informal settlements (squatter settlement) and Kirtipur housing project (KHP) (adopted from [40]).

In September 2003, the political twist reinstated the former Mayor. The agreement was made to grant 8 million rupees (US\$80,000; US\$ equivalent to 100 rupees was considered as the conversion rate) for relocating the affected informal settlers [40]. However, the allocated budget was not enough. To align the financial arrangement from various organizations it was necessary to arrange a viable framework to administer the fund. Therefore, a finance fund was set up in the form of Urban Community Support Fund (UCSF) with financial contributions of the Kathmandu Municipality, Asian Coalition for Housing Rights, Slum Dwellers International, Action Aid Nepal and Water Aid Nepal. Lumanti administered the UCSF. A total of 20 million rupees (US\$20,000) was eventually raised [40]. The objectives of the UCSF were set as follows [41]:

- To provide secure housing ownership to the target group by providing low-interest financial support for purchasing land and for housing improvement

- To provide financial access to the target group by providing capital for income generating activities

- To support the target group in fulfilling their basic social and physical needs

- To support in access to land for a civil society for developing low-income housing 
Table 3. overviews of activities and actors involved in KHP (Source: [40] and Author Field Visit).

\begin{tabular}{|c|c|c|c|c|c|}
\hline Scale and Level & Time Line & Activities & $\begin{array}{l}\text { Civil } \\
\text { Society }\end{array}$ & Market & Government \\
\hline \multirow{5}{*}{$\begin{array}{l}\text { Policy and } \\
\text { Strategy level }\end{array}$} & January 2002 & $\begin{array}{l}\text { Agreement signed by KMC mayor to provide alternative housing provision with Lumanti, } \\
\text { squatter federations. The agreement was about giving money for paying rent to genuine } \\
\text { informal settlers (US \$ } 27 \text { per month) for the duration of three months after the settlement } \\
\text { gets demolished }\end{array}$ & $\checkmark$ & $x$ & $\checkmark$ \\
\hline & April 2002 & $\begin{array}{l}\text { The settlements were demolished. Land to resettle the evicted informal settlers was inspected } \\
\text { with criteria of accessibility and affordability by Lumanti together with squatter federations }\end{array}$ & $\checkmark$ & $x$ & $\checkmark$ \\
\hline & June 2002 & The agreement made by the former KMC mayor was not approved by the new government & $\checkmark$ & $x$ & $\checkmark$ \\
\hline & September 2003 & $\begin{array}{l}\text { The former mayor was reinstated. The plan to resettle the evicted informal settlers } \\
\text { was forwarded }\end{array}$ & $x$ & $x$ & $\checkmark$ \\
\hline & May 2003 & $\begin{array}{l}\text { The necessity of a fund for relocation and providing housing for informal settlers was realized. } \\
\text { UCSF was established with the collaboration of Kathmandu } \\
\text { Municipality, Asian Coalition for Housing Rights, Slum Dwellers International, Action Aid } \\
\text { Nepal and Water Aid Nepal }\end{array}$ & $\checkmark$ & $x$ & $\checkmark$ \\
\hline \multirow{7}{*}{ Project Level } & \multirow{6}{*}{$\begin{array}{l}\text { May } 2003 \\
\text { onwards }\end{array}$} & The land area of $32.825 \mathrm{sq} . \mathrm{ft}$ was purchased for 30 lakhs ( 30,000 US\$) by the UCSF & $\checkmark$ & $x$ & $x$ \\
\hline & & 44 double storey houses are constructed under the management of Lumanti & $\checkmark$ & $x$ & $x$ \\
\hline & & $\begin{array}{l}\text { The committee to manage overall housing project was formed under Lumanti, including the } \\
\text { informal settlers' federation }\end{array}$ & $\checkmark$ & $x$ & $x$ \\
\hline & & $\begin{array}{l}\text { Construction of access road was supported by Department of Urban Development and } \\
\text { Building Construction (DUDBC) }\end{array}$ & $\checkmark$ & $x$ & $\checkmark$ \\
\hline & & $\begin{array}{l}\text { Construction of Rain water harvesting system and other water and sanitation facilities was } \\
\text { supported by UN-Habitat and Water-Aid (INGOs) }\end{array}$ & $\checkmark$ & $x$ & $x$ \\
\hline & & $\begin{array}{l}\text { Building design and its construction were contracted to the Astra Pvt. Ltd. The informal } \\
\text { settlers and Lumanti were involved in approving the design }\end{array}$ & $\checkmark$ & $\checkmark$ & $x$ \\
\hline & December 2005 & $\begin{array}{l}\text { Inauguration of the housing Handover of Keys from lottery system in the presence of Lumanti, } \\
\text { squatters federation, and Municipality }\end{array}$ & $\checkmark$ & $x$ & $\checkmark$ \\
\hline
\end{tabular}


KHP at the Strategy Level

A six ropani (equivalent to 32.825 sq. $\mathrm{ft}$ ) piece of land was purchased at Paliphal in Kirtipur. The cost of land was 3 million Rupees (US\$300,000) per ropani and was covered by the Urban Community Support Fund (UCSF). This project was considered the first project funded by the UCSF for access to land and housing for low-income groups. The choice of location was agreed on by taking into accounts the needs and preferences of the beneficiaries. The available budget and accessibility from the center of the city were important criteria that were considered. Furthermore, the social stigma attached to the informal settlers was also a prime criterion because the existing communities might be offended by the relocation of the informal settlers near their neighborhoods. Therefore, the location was away from the existing neighborhood.

\subsection{Allocation of Land and Housing from the Market}

Forty-four dwellings were constructed with active participation from the beneficiaries. Primarily, the nature and type of houses, materials, and facilities were determined by the beneficiaries based on the repayment amount. The residents needed to pay monthly around Rs 2000 (US\$20). It consisted of a row of housing with a common open space that can be used as playgrounds and for other purposes. Two types of housing plans were prepared. The housing price differed according to the layout of the toilet. The monetary value of houses was Rs 330,000 (US\$3300) and Rs 350,000 (US\$3500) respectively. The house was owned by UCSF until the loan was repaid. The UCSF had provided the loan to the settler in the interest rate of $3 \%$ per annum and the repayment period of 15 years. The private housing developer, Astra Pvt. Ltd. was involved as a consulting developer for the planning and design of the house in KHP.

KHP at the Project Level

In the following sub-section, the KHP project is explained in its various project stages.

\subsection{Project Identification and Feasibility Phase}

- Involvement of community in the feasibility plan of land use

Most of the residents (18 out of 27 respondents) stated that they were involved in the feasibility phase of the project (See Figure 4). As reported by Sengupta and Sharma [40], the choice of the location of the site for relocation was considered according to the need and preference of the residents within the available budget. The present location was considered as an optimal choice in accordance with the criteria of affordable land for low-income housing. However, a compromise was made between integration with existing communities and impact on the employment. Of 27 respondents, 20 mentioned that the current land use and its location was not accessible enough to support their income generation activities (see Figure 5). Most of the residents are vegetable vendors, house cleaners in the core area of the city which is some $10 \mathrm{Km}$ from the current relocated area.

- Technical Support in the land development

Local knowledge was applied in order to understand the feasibility of the site for relocation. The private developers were not found to be involved in the feasibility of the land development process. The technical support and manpower, such as surveyors for surveying the feasibility of area for the low-income housing, were not selected from private sectors. Moreover, the technical recommendations from highly skilled expertise for proper drainage provision seemed to be lagging. 


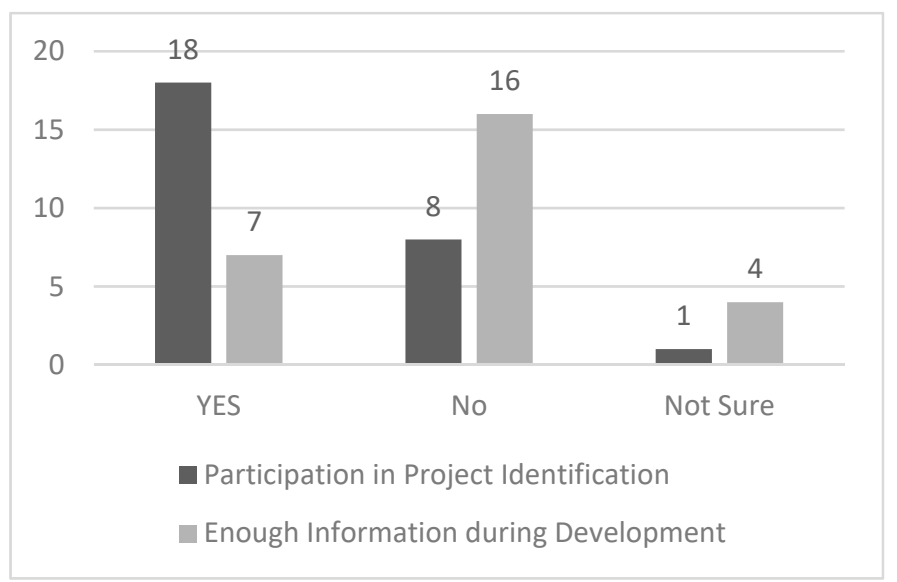

Figure 4. Residents' view on the involvement in the KHP Project.

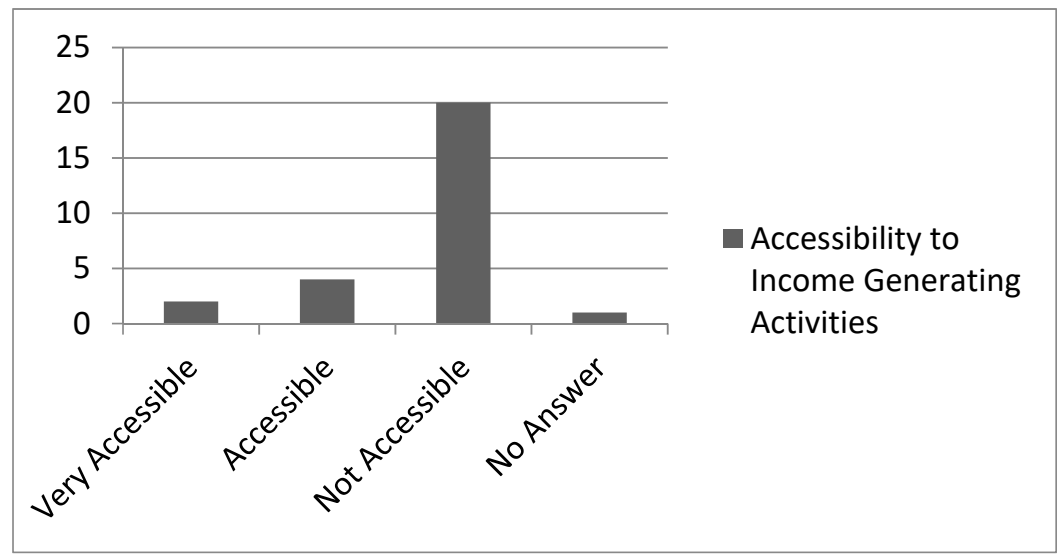

Figure 5. Residents' view on the accessibility to income generating activities.

\subsection{Project Planning and Design}

- Community involved in the land use plan

The land use pattern of KHP consisted of two common open spaces. The use of the open spaces was not defined during the project. The open space was allocated to make a garden (interview: officials from Lumanti). The land use plan did not seem supportive in improving the economic condition. Only four respondents stated that their economic activities were supported by the present location. In contrast, 17 residents stated that their economic activities were not supported at the current location Figure 6. Moreover, it was observed that the residents were using the open space for carrying out activities to enhance their financial situation (Figure 7). This was again attributed to reduced accessibility of the current location from the areas of income generation as shown in (Figure 5) as well as lack of land allocation for conducting their income generating activities.

With regard to financial support, there was a general view that the payback method of housing loan supported their financial condition. As stated by three respondents, the amount they had to pay monthly for the house was less than the payment for rental accommodation (see Figure 7). Most of the residents (16 out of 27 respondents) felt that the information given during the project planning was not enough. This was reflected in the view of one settler as follows:

"In the initial design of the house, there was concrete slab in the roof but during construction, the roof is covered with Zinc. We cannot use the space in rooftop" (residents comment). 
The management committee of the housing was formed under the aegis of Lumanti. The management committee included members of the residents themselves. The committee was mandated to manage all the transactions for the project, including making payments to the contractors/consultants and decision making on the design/layout.

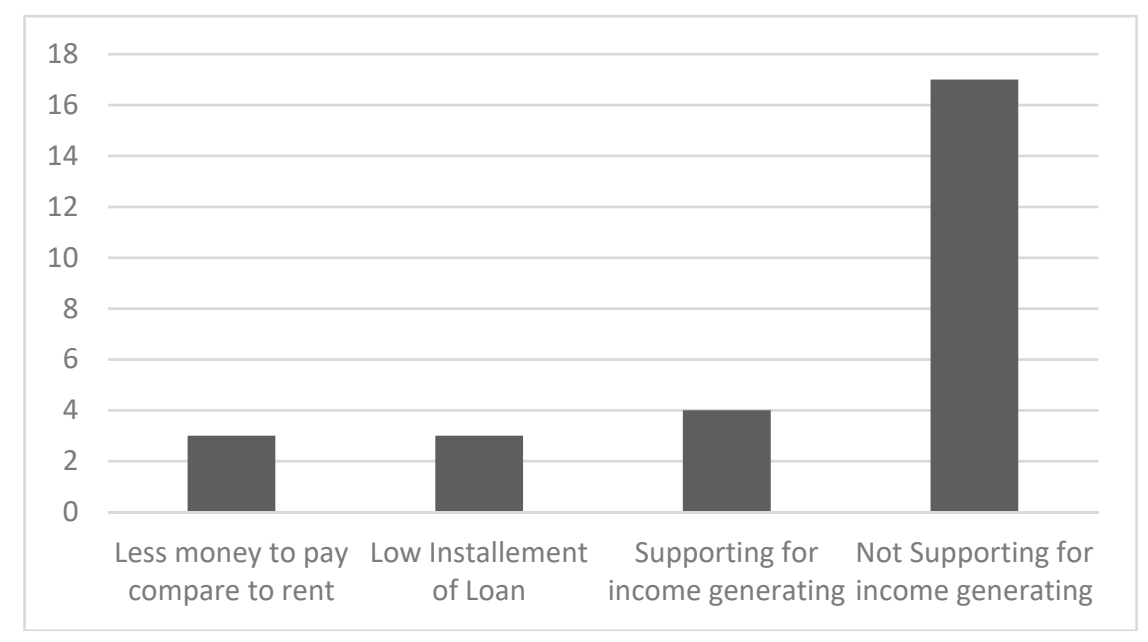

Figure 6. Residents' perception on land use for economic improvement.

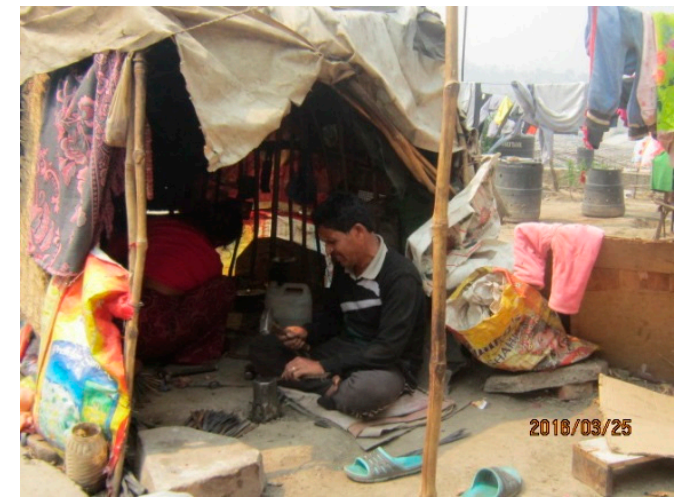

(a)

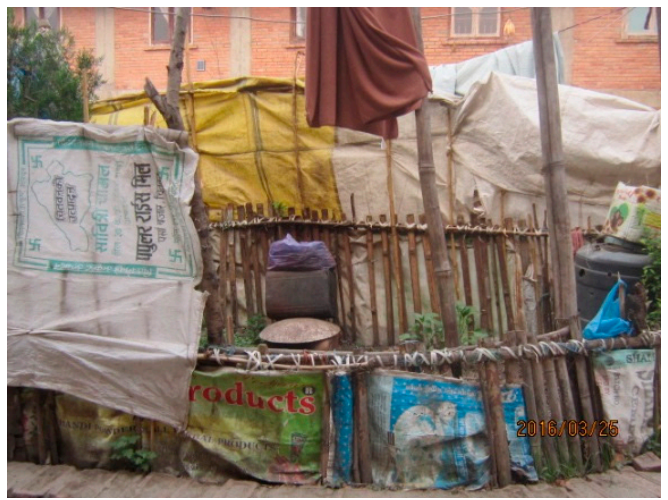

(b)

Figure 7. Common open space used for social entrepreneurship by an individual resident (a) KHP residents using common space for making metal souvenirs; (b) KHP residents using common space for farming.

\section{- Technical Support for Land and Housing Development}

There were various government and non-government organizations involved in the construction of service infrastructure. The stone paving in the access road was carried out by the government sector (DUDBC). Two wells were constructed and rainwater harvesting was introduced with the support of UN-Habitat. Three underground tanks were built to collect rainwater. For the optimum usage of wastewater, a treatment plant was also installed so that treated water could be reused for various purposes like washing, cleaning etc. The water filter was constructed by Centre for Integrated Urban Development (CIUD) and Water Aid contributed to the construction of water and sanitation [40]. Astra Development Network Pvt Ltd. (Kathmandu, Nepal) was involved in the design and construction of the housing unit. The interview with Astra officials revealed that the consultant fee was reduced in the design and construction of the building. The letter of appreciation was given to the consulting firm by UCSF for the support they had given. 


\subsection{In Project Monitoring}

- Involvement of the community and use of land for enhancing economic condition

The residents were not allowed to sell their housing unit on the free market. The awareness regarding the permission required by the management committee to sell their housing unit was shown by 17 out of 27 respondents. The value of their housing unit and the beneficiaries were determined by the management committee. The residents did not seem to know whether they could use their housing unit for rental purposes. Nineteen respondents perceived that the value of their housing unit should rise due to the increase in their land value resulting from the increase in land price in the vicinity. Nonetheless, eight respondents did not perceive any changes in their housing unit. They were aware that the value in the vicinity did not apply to their housing unit, as it was not possible to sell it at market value. Moreover, they did not possess legal documents of rights to land and house until they paid their entire loan. Therefore, the house was not considered as the increment in price by the respondents. Regarding the willingness to sell their house, 10 out of 27 respondents were unwilling, whereas 15 seemed to be in a dilemma.

The data on the repayment of the loan in 2016 showed that out of 42 residents, only 10 residents were able to pay the full amount (see Figure 8). The allocated period for loan repayment was 15 years. However, more than $50 \%$ of the residents had only paid less than half of the total amount within the period of 11 years. This reflects that during the given period, the residents might not able to repay the entire amount. There was already a case where one of the house was sold through the management committee because the owner was not able to pay the amount of the loan within the allocated time (Interview with the residents: 2016).

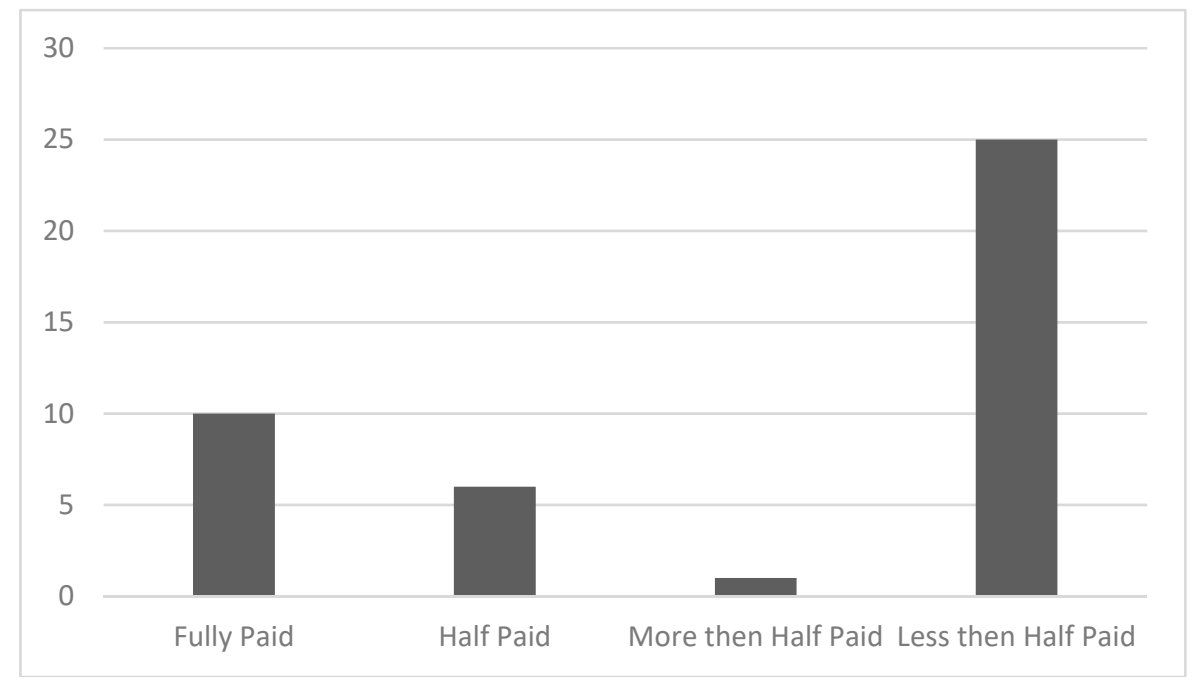

Figure 8. Loan repaid by residents in 2016 (Source: Lumanti).

The lack of clear legal provision on the exemption from the land and housing tax for low-income housing residents created social unrest among residents. The residents were in fear of displacement from the current settlement due to failure to pay municipality tax for land and housing. During the interview with a government actor, it was revealed that there was no provision to redeem the tax for low-income housing (Interview: Kirtipur Municipality officials 2016). Therefore, the residents did not feel secure from the perspective of land tenure due to tax issues on one hand and on the other hand, they were in a dilemma if they would be able to pay the loan of the house.

Humiliation and social stigma existed among the residents (see Figure 9). It revealed that the current land use pattern and tenure were not able to wipe out the social stigma towards informal 
settlers. However, as they were able to buy the house, some self-respect and dignity could be seen among the residents. This was reflected in the view of one of the residents as below:

"We are still addressed as a "Sukumbashi (Sukumbashi is local terminology applied to define informal settlers)" basically when we go to fetch water in the local community. We are paying money for the house so we should not be treated as "Sukumbashi"

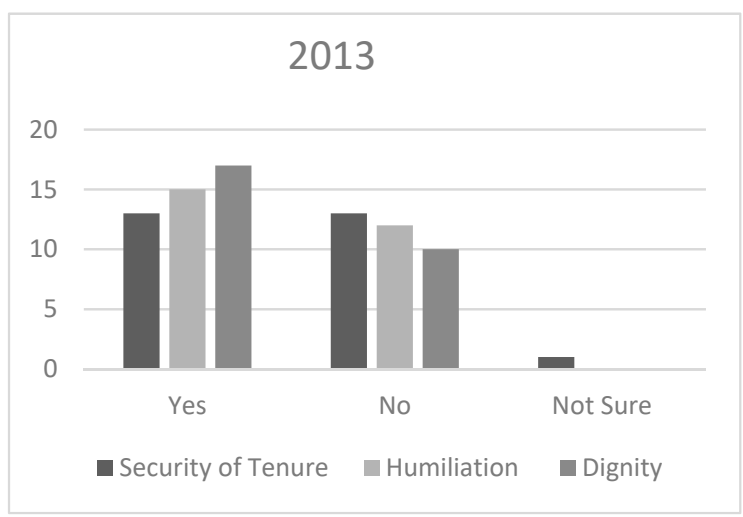

(a)

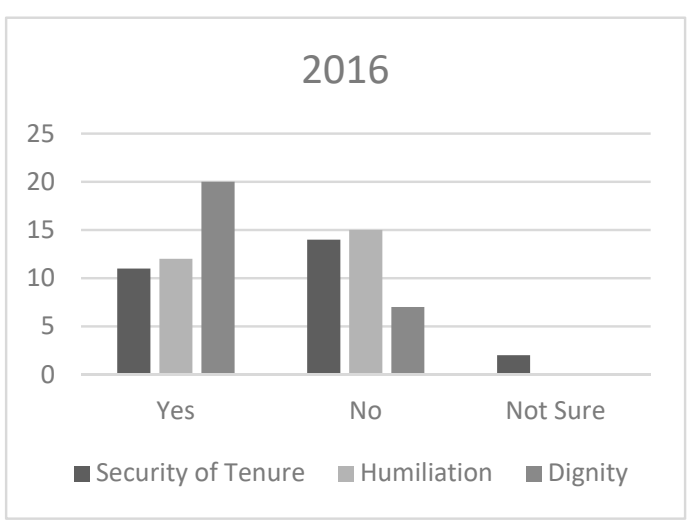

(b)

Figure 9. Residents' perception on social aspect (a) KHP residents' perception (2013); (b) KHP residents' perception (2016).

- Technical Support for the services

Most of the residents were satisfied regarding living condition in the resettlement site as compared to their previous settlements. Nonetheless, a few seemed to remain dissatisfied as observed in both periods. The residents were dissatisfied regarding the services. During the field visit in 2013, they complained about the electricity provision, drinking water, and sewer problem. Although each household had a sub-meter, however, they needed to pay more according to the main meter, which was always higher, than their own use. The complaint still existed during a field visit in 2016. It revealed that the provision of individual electricity meters was linked with the use of land under individual ownership. Since the household does not have individual possession of the land occupied by their housing unit, they were not able to get the individual electric meter and water tap.

\section{Analysis and Discussion}

In this section, social entrepreneurship and CSR are analyzed and discussed in two-level (policy strategy and project level).

\subsection{Social Entrepreneurship}

\subsubsection{Policy and Strategy Level}

The case of the Kirtipur Housing Project (KHP) has shown that the "action space" of NGO and civil society was created by formulating Urban Community Support Fund (UCSF). The UCSF has a social goal of providing financial assistance for the low-income groups while buying the land for housing or improving the housing that aligns with the characteristic of social entrepreneurship as defined by Rahim and Mohtar [42]. The "action space" created through the UCSF for accessing land from the formal land market contributed to the success of the resettlement project. The land is the critical factor for housing low-income groups [4,43]. A similar initiative has been shown in the study of Tripathi and Agarwal [31]. The financial cooperative that was established by the informal settlers' federation with the support from the NGOs contributed as social entrepreneurship that led to the economic empowerment of the informal settlers, thus, enabling them to invest in land and 
housing. The UCSF also seems to be an approach towards social entrepreneurship as it provides financial assistance for informal settlers in income generating activities and supports them to buy land for housing or improving the housing. This aligns with Wilson and Gran [44], who have also reported the important role of NGOs and Community based organization in bridging the market gap for low-income groups.

However, the "action space" of NGOs and civil society in the form of social entrepreneurship had not been incorporated into the legal framework. Though the "action space" was created on the civil society side by conceptualizing the social entrepreneurship, there was a regulatory vacuum, meaning that no intervention in the market sector to enhance social entrepreneurship existed. The land and housing tax for the KHP was calculated under the same regulations as it was calculated for a housing unit developed by the private developer. The regulatory vacuum regarding land and housing tax redemption for low-income housing shows a lack of "action space" of civil society in achieving the social objectives.

Moreover, the role of NGOs and civil society as social entrepreneurs has not been incorporated into policy and into the process of delivering housing for low-income groups at a national level, but their role has been limited only in the project level. In addition to the case of KHP, the eviction case of one of the informal settlements that reside along the river of Kathmandu in the year 2002, as described by Shrestha et al. [45] and Shrestha and Aranya [46], reveals a failing case of resettlement. The rationale was the difficulties in the access to land for the relocation due to the lack of market legitimacy for allocating land for low-income housing. The land developed for profit-making is rarely allocated for housing low-income groups [15]. In addition, the social stigma associated with the value of land near the low-income housing is another reason for the difficulty in the access to land [26]. In spite of this, the UCSF has succeeded in providing access to land with market legitimacy but there still seems a lack of the social legitimacy of the residents. The intervention strategies to fulfill social legitimacy has been highlighted in the study of Shrestha et al. [7]. For instance, creating job opportunities in relocated sites and, provision of security of tenure. Hence, the scaling up of the social entrepreneurship of the NGOs and civil society groups at the national level seems important in order to increase the chances for the access to land to resettle the informal settlers.

\subsubsection{Project Level}

The KHP case has shown that the current land use pattern in the project area does not contribute to the economic enhancement of the residents. It reveals that there is a lack of social entrepreneurship with respect to the land use within the project. As described by Ferguson [47], the success of the resettlement project depends upon the use of land such that it supports the social entrepreneurship of the residents in order to generate their income. The lack of "action space" in order to use the land for social entrepreneurship has been reflected in the lagging of the repayment of the loan by the residents within the specific period. This justifies the Kigochie [23] argument about the necessity of home-based enterprises in the newly relocated site.

The case reveals that the residents are involved from the initial period of the KHP. As highlighted by Sengupta and Sharma [40], the KHP is one of the successful community-led resettlement projects. Patel et al. [24] also mentioned that community-led governance considers social norms and value creating social legitimacy. However, the residents' views reveal that KHP has not been able to cater to the social values. The land use pattern does not seem to contribute in bringing social cohesion among the residents.

In addition, the land parcel that has been allocated for housing unit is not under the individual ownership of the residents. These legal issues regarding land ownership and use of land have triggered financial unrest among residents. Further, in the KHP, there is a restriction on the access to electricity meter in the individual housing unit. The provision of combined electricity meter has created social conflict among residents because they have to pay the electricity charge equally despite less consumption. Further, as mentioned by De Soto [48] in his book "The Mystery of Capital", 
the residents could not use their housing unit for the mortgage because of lack of formal title of land. In contrast to De Soto [48], Gilbert [49] has clearly mentioned that the formal titles could not support low-income groups in the access to credit from formal financial institutions, which provide loans with high-interest rates. In addition, Durand-Lasserve [15] has explained the market gentrification of the informal settlers after issuing formal title of land use. However, there are various cooperatives that were focused on social entrepreneurs and provide a loan to low-income groups [31]. In Nepal, as well, there are cooperatives initiated by informal settlers federations established with a social goal rather than a financial goal. These cooperatives are facilitating the financial support to the low-income groups. The detail of the cooperatives has been explained in $[45,50]$.

Despite above-mentioned weakness in the case about the land use pattern as being not supportive in the social entrepreneur, however, modality adopted by project by not allowing the residents to sell the housing unit by themselves created "action space" for civil society to oppose market gentrification.

\subsection{Corporate Social Responsibility}

\subsubsection{Policy and Strategy Level}

Various authors [35,36] have argued that the CSR is a feasible approach to create an "action space" of private developers in allocating a certain percentage of their developed land for low-income housing. In this regard, the KHP case reveals that the action of the private actors has not been conducted under the framework of Corporate Social Responsibility (CSR). The private developers were not involved as a market actor in the process of land delivery for housing low-income groups. Instead, they were hired as contractors for planning, design, and construction of the housing unit.

The lack of inclusive land policies and strategies to deliver land for housing low-income groups enforced the NGOs and civil society to access land from the formal market. As such, the "action space" is pulled towards the market logic. This has given rise to the market led governance in the land and housing sector that is oriented for developing land for economic growth. As a result, only high-income groups were catered. As explained by Foxon [8], the high-income groups are the compliant consumer in the market form of land delivery.

Therefore, the intervention in the market form of land delivery for housing the low-income groups is required which was articulated in [51]. Moreover, while doing so, market legitimacy is important to be considered. As Hong Sharon Yam and Stanley McGreal [52] mentioned, private organization requires market legitimacy. In this line, Adams et al. [35] have mentioned market instruments like tax redemption and provision of development rights that can be integrated into CSR for allocating land for housing low-income groups.

\subsubsection{Project Level}

Considering the use of land at the project level, Hong Sharon Yam and Stanley McGreal [52] mentioned that private developers can fulfil CSR by developing recreational park, green spaces, and good infrastructures. However, the housing for low-income groups is sensitive to house price and fulfills the basic accommodation needs, rather than other recreational facilities. Therefore, private developers can contribute in providing technical expertise to use the land effectively in constructing housing at a low price. The KHP case reveals the private consultant had designed the housing unit of the project. Furthermore, the consultant did not seem to be involved within the framework of CSR like providing subsidies and waiving the consulting fee in the housing design, consultation in applying low-cost technology. The lack of private sector involvement in the case of KHP was mentioned in the study of [40] as well.

The result of the lack of private sector involvement was illustrated in the monitoring and maintenance phase of the project. The lack of technical support in the maintenance of land that was used for the rainwater harvesting had left the infrastructure unused. This technical constraint can be overcome by creating the "action space" of the private sector within the CSR framework [32]. 


\section{Conclusions}

In this paper, we have explored the concept of "action space" and translated this concept into housing for low-income groups by conceptualizing the "Social Entrepreneur" and "Corporate Social Responsibility" (CSR). The civil society has created its own "action space" by setting the Urban Community Support Fund (UCSF) for the provision of land and housing to the low-income groups. This shows the shift from the managerial governance pattern-the government as the provider-towards the entrepreneur-the government as the facilitator. The case shows the trend of the social entrepreneur by formulating a platform like UCSF, however, this initiative remained at the project level. The scaling-up of the concept of "Social Entrepreneur" to the policy level in order to formulate national strategies towards access to land for housing low-income groups remains a vacuum. Ultimately, this indicates that the intervention towards managing the informal settlements at the country level is lagging.

While referring to the market actors like private developers, the case clearly demonstrates that there is no binding legal framework to pull the private sectors towards the social goal. The concept of CSR is not framed in the regulation of the private sector in the provision of land for housing low-income groups. Due to the lack of private sector, involvement in the housing delivery for low-income groups has been skewed towards government and civil society. This has resulted in a short-term solution at the project level.

Besides the fact that the translation of the Social Entrepreneur and CSR concept to the policy and strategy level is important, it should be translated into project level as well. Looking into the project level, the case shows how the lack of land use plan that supports the social entrepreneurship of the individual residents reflects a failure to capture social legitimacy. In addition, the lack of market actors that play a sufficient role in the consideration of technical support in the context of use of land is lacking. The "action space" created for private developers in the concept of CSR seems to affect an effective approach towards solving housing issue from a land perspective.

This paper contributes at the conceptual level to analyzing the governance patterns. The analytical framework of action space has been able to capture the dynamics involved in the push and pull of the action space between market actors and civil society actors, as well as the effects of this dynamism on the allocation of land for low-income housing. We believe that the use of the analytical framework of action space offers an interesting perspective on analyzing the governance pattern between market actors and civil society actors in general. In addition to the conceptual contribution, this study makes a societal contribution to the process of access and allocation of land for housing low-income groups in particularly. Housing for low-income groups has remained an issue in the global south for decades. However, most of the housing-related studies have focused on designing affordable housing rather than tackling the land issues for low-income housing. In this context, we feel that this study contributes to the existing literature on housing studies by conceptualizing the notions of Social Entrepreneur for access and CSR for allocating land for low-income housing. In doing so, it further assists in narrowing the gap between market and social legitimacy in the housing the low-income groups, taking the land issue as a point of departure.

Finally, this paper concludes that the concept of Social Entrepreneur and CSR can narrow the gap between social legitimacy and market legitimacy by balancing the "action space" of the market and civil society actors. Narrowing this gap needs attention both at the project level as well as scaling up to the national level in regard to access to and allocation of land for low-income housing for managing the informal settlements.

Author Contributions: This paper is the part of the PhD research of R.S.; J.Z. and M.B. have contributed to and supervised the interpretation of the data. The manuscript was written by R.S. with contributions from J.Z., F.M. and M.B. in the overall write up of the paper.

Funding: This study was funded by Netherland Government Scholarship (NUFFIC) and ITC Foundation Fellowship Program (IFP 17.1.17). 
Acknowledgments: The authors like to acknowledge the Netherlands government fellowship program (NUFFIC), Faculty of Geo-Information Science and Earth Observation (ITC) of the University of Twente and Kathmandu University for supporting this research. The authors is grateful for all the interviewee from government and non-government organizations who had provided the information.

Conflicts of Interest: The Authors declare no conflicts of interest.

\section{References}

1. Mason, S.; Fraser, C. Image sources for informal settlement management. Photogramm. Rec. 1998, 16, 313-330. [CrossRef]

2. Augustinus, C. Improving Access to Land and Shelter. In Land governance in support of the MDGs: Responding to new challenges, Proceedings of the World Bank and International Federation of Surveyors Conference, Washington, DC, USA, 9-10 March 2009; pp. 9-10.

3. Gutberlet, J.; Kain, J.-H.; Nyakinya, B.; Ochieng, D.H.; Odhiambo, N.; Oloko, M.; Omolo, J.; Omondi, E.; Otieno, S.; Zapata, P. Socio-environmental entrepreneurship and the provision of critical services in informal settlements. Environ. Urban. 2016, 28, 205-222. [CrossRef]

4. Satterthwaite, D. Getting land for housing; what strategies work for low-income groups? Environ. Urban. 2009, 21, 299-307. [CrossRef]

5. Yap, K.S. The enabling strategy and its discontent: Low-income housing policies and practices in Asia. Habitat Int. 2016, 54 Pt 3, 166-172. [CrossRef]

6. Faraj, Y. Land Strategies-Land Strategies to Address Low-Income Housing in Suleimany City, Kurdistan Regional Government. Master's Thesis, Delft University of Technology, Delft, The Netherlands, 2014.

7. Shrestha, R.; Tuladhar, A.; Zevenbergen, J.; Banskota, M. Urban land governance: “Action space”, legitimacy of and intervention strategies for urban informal settlements in Nepal. Nord. J. Surv. Real Estate Res. 2016, 11, 20-50.

8. Foxon, T.J. Transition pathways for a UK low carbon electricity future. Energy Policy 2013, 52, 10-24. [CrossRef]

9. Blessing, A. Magical or monstrous? Hybridity in social housing governance. Hous. Stud. 2012, 27, $189-207$. [CrossRef]

10. Czischke, D.; Gruis, V.; Mullins, D. Conceptualising social enterprise in housing organisations. Hous. Stud. 2012, 27, 418-437. [CrossRef]

11. Stoker, G. Governance as theory: Five propositions. Int. Soc. Sci. J. 1998, 50, 17-28. [CrossRef]

12. Suchman, M.C. Managing legitimacy: Strategic and institutional approaches. Acad. Manag. Rev. 1995, 20, 571-610. [CrossRef]

13. Thomas, C. The Concept of Legitimacy and International Law. 2013. Available online: https://papers.ssrn. com/sol3 / papers.cfm?abstract_id=2265503 (accessed on 7 June 2016).

14. Hawn, O.; Chatterji, A.; Mitchell, W. Two Coins in One Purse? How Market Legitimacy Affects the Financial Impact of Changes in Social Legitimacy: Addition and Deletion by the Dow Jones Sustainability Index; Duke University: Durham, NC, USA, 2011.

15. Durand-Lasserve, A. Market-driven evictions and displacements: Implications for the perpetuation of informal. In Informal Settlements: A Perpetual Challenge? Juta and Company Ltd.: Cape Town, South Africa, 2006; p. 207.

16. Ndezi, T. The limit of community initiatives in addressing resettlement in Kurasini ward, Tanzania. Environ. Urban. 2009, 21, 77-88. [CrossRef]

17. Patel, S.; D'Cruz, C.; Burra, S. Beyond evictions in a global city: People-managed resettlement in Mumbai. Environ. Urban. 2002, 14, 159-172. [CrossRef]

18. Yntiso, G. Urban development and displacement in Addis Ababa: The impact of resettlement projects on low-income households. East. Afr. Soc. Sci. Res. Rev. 2008, 24, 53-77. [CrossRef]

19. Keuk, J.N.; Abdullah, Y.A.; Hamdan, H. Eradicating squatters through resettlement programme: A conceptual paper. In Proceedings of the 4th International Building Control Conference, Kuala Lumpur, Malaysia, 7-8 March 2016; p. 00023.

20. Amado, M.P.; Ramalhete, I.; Amado, A.R.; Freitas, J.C. Regeneration of informal areas: An integrated approach. Cities 2016, 58, 59-69. [CrossRef] 
21. Garau, C. Focus on citizens: Public engagement with online and face-to-face participation-A case study. Future Internet 2012, 4, 592-606. [CrossRef]

22. Kågström, M.; Richardson, T. Space for action: How practitioners influence environmental assessment. Environ. Impact Assess. Rev. 2015, 54, 110-118. [CrossRef]

23. Kigochie, P.W. Squatter rehabilitation projects that support home-based enterprises create jobs and housing: The case of Mathare 4a, Nairobi. Cities 2001, 18, 223-233. [CrossRef]

24. Patel, S.; Baptist, C.; D'Cruz, C. Knowledge is power-informal communities assert their right to the city through SDI and community-led enumerations. Environ. Urban. 2012, 24, 13-26. [CrossRef]

25. Turk, S.S.; Altes, W.K.K. The planning system and land provision for social housing in turkey. Hous. Financ. Int. 2010, 25, 26.

26. Needham, B.; de Kam, G. Understanding how land is exchanged: Co-ordination mechanisms and transaction costs. Urban Stud. 2004, 41, 2061-2076. [CrossRef]

27. Foxon, T.J.; Hammond, G.P.; Pearson, P.J.; Burgess, J.; Hargreaves, T. Transition pathways for a UK low carbon energy system: Exploring different governance patterns. In Proceedings of the European Conference on Sustainability Transitions: Dynamics and Governance of Transitions to Sustainability, Amsterdam, The Netherlands, 4-5 June 2009; pp. 4-5.

28. Bjerke, B.; Karlsson, M. Social Entrepreneurship: To Act as if and Make a Difference; Edward Elgar Publishing: Cheltenham, UK, 2013.

29. Shrestha, P. Urban governance, planning and housing policy-shift from managerialism to entrepreneurialism. In Proceedings of the N-AERUS XI Assessing and Exploring the State of Urban Knowledge: Its Production, Use, and Dissemination in the Cities of the South, Brussels, Belgium, 28-30 October 2010.

30. Rhodes, M.L.; Donnelly-Cox, G. Hybridity and social entrepreneurship in social housing in Ireland. VOLUNTAS: Int. J. Volunt. Nonprofit Organ. 2014, 25, 1630-1647. [CrossRef]

31. Tripathi, R.; Agarwal, S. The role of social entrepreneurs in the development of cooperatives for catalyzing empowerment in the slum areas of India. Afr. J. Bus. Manag. 2013, 7, 3259.

32. Othman, A.; Mia, B. Corporate social responsibility for solving the housing problem for the poor in South Africa. J. Eng. Des. Technol. 2008, 6, 237-257. [CrossRef]

33. Badulescu, A.; Badulescu, D.; Saveanu, T.; Hatos, R. The relationship between firm size and age, and its social responsibility actions-Focus on a developing country (Romania). Sustainability 2018, 10, 805. [CrossRef]

34. Tang, Y.; Ma, Y.; Wong, C.W.; Miao, X. Evolution of government policies on guiding corporate social responsibility in china. Sustainability 2018, 10, 741. [CrossRef]

35. Adams, D.; Payne, S.; Watkins, C. Corporate social responsibility and the UK housebuilding industry. In Corporate Social Responsibility in the Construction Industry; Taylor \& Francis: London, UK, 2008; pp. 235-258.

36. Gooding, T. Low-income housing provision in Mauritius: Improving social justice and place quality. Habitat Int. 2016, 53, 502-516. [CrossRef]

37. Wilson, C.; Morrison, T.; Everingham, J.-A.; McCarthy, J. Steering social outcomes in America's energy heartland state and private meta-governance in the Marcellus shale, Pennsylvania. Am. Rev. Public Admin. 2017, 47, 929-944. [CrossRef]

38. Cash, D.W.; Adger, W.N.; Berkes, F.; Garden, P.; Lebel, L.; Olsson, P.; Pritchard, L.; Young, O. Scale and cross-scale dynamics: Governance and information in a multilevel world. Ecol. Soc. 2006, 11, 8. [CrossRef]

39. Gibson, C.C.; Ostrom, E.; Ahn, T.K. The concept of scale and the human dimensions of global change: A survey. Ecol. Econ. 2000, 32, 217-239. [CrossRef]

40. Sengupta, U.; Sharma, S. No longer sukumbasis: Challenges in grassroots-led squatter resettlement program in Kathmandu with special reference to Kirtipur housing project. Habitat Int. 2009, 33, 34-44. [CrossRef]

41. Lumanti. New Beginnings: Housing the Urban Poor; Lumanti: Kathmandu, Nepal, 2005.

42. Rahim, H.L.; Mohtar, S. Social entrepreneurship: A different perspective. Int. Acad. Res. J. Bus. Technol. 2015, 1, 9-15.

43. Nientied, P.; Kalim, S.I. Policy constraints on planning land for low-income groups in Karachi. Habitat Int. 1986, 10, 79-92. [CrossRef]

44. Wilson, E.; Gran, M.G. NGOs as Market Actors: Roles and Responsibilities in Supporting Small Producers in Low-Income Countries; International Institute for Environment and Development (IIED): London, UK, 2007. 
45. Shrestha, R.; Tuladhar, A.; Zevenbergen, J.; Banskota, M. “Decades of struggle for space”: About the legitimacy of informal settlements in urban areas. In Proceedings of the FIG Cogress, Kuala Lumpur, Malaysia, 16-21 June 2014; pp. 16-21.

46. Shrestha, P.; Aranya, R. Claiming invited and invented spaces: Contingencies for insurgent planning practices. Int. Plan. Stud. 2015, 20, 424-443. [CrossRef]

47. Ferguson, J. Formalities of poverty: Thinking about social assistance in neoliberal South Africa. Afr. Stud. Rev. 2007, 50, 71-86. [CrossRef]

48. De Soto, H. The Mystery of Capital: Why Capitalism Succeeds in the West and Fails Everywhere Else; Basic Books: New York, NY, USA, 2000.

49. Gilbert, A. On the mystery of capital and the myths of Hernando De Soto: What difference does legal title make? Int. Dev. Plan. Rev. 2002, 24, 1-19. [CrossRef]

50. Tanaka, M. From confrontation to collaboration: A decade in the work of the squatters' movement in Nepal. Environ. Urban. 2009, 21, 143-159. [CrossRef]

51. Paris, C. International perspectives on planning and affordable housing. Hous. Studi. 2007, 22, 1-9. [CrossRef]

52. Hong Sharon Yam, L.; Stanley McGreal, W. House-buyers' expectations with relation to corporate social responsibility for Malaysian housing. Int. J. Hous. Mark. Anal. 2010, 3, 132-145. [CrossRef]

(C) 2018 by the authors. Licensee MDPI, Basel, Switzerland. This article is an open access article distributed under the terms and conditions of the Creative Commons Attribution (CC BY) license (http://creativecommons.org/licenses/by/4.0/). 